\title{
Rebuilding soil hydrological functioning after swidden agriculture in eastern Madagascar
}

Zwartendijk, B. W.; van Meerveld, H. J.; Ghimire, C. P.; Bruijnzeel, L. A.; Ravelona, M.; Jones, J.P.G.

\section{Agriculture, Ecosystems and Environment}

DOI:

10.1016/j.agee.2017.01.002

Published: 15/02/2017

Peer reviewed version

Cyswllt i'r cyhoeddiad / Link to publication

Dyfyniad o'r fersiwn a gyhoeddwyd / Citation for published version (APA):

Zwartendijk, B. W., van Meerveld, H. J., Ghimire, C. P., Bruijnzeel, L. A., Ravelona, M., \& Jones, J.P. G. (2017). Rebuilding soil hydrological functioning after swidden agriculture in eastern Madagascar. Agriculture, Ecosystems and Environment, 239, 101-111.

https://doi.org/10.1016/j.agee.2017.01.002

\footnotetext{
Hawliau Cyffredinol / General rights

Copyright and moral rights for the publications made accessible in the public portal are retained by the authors and/or other copyright owners and it is a condition of accessing publications that users recognise and abide by the legal requirements associated with these rights.

- Users may download and print one copy of any publication from the public portal for the purpose of private study or research.

- You may not further distribute the material or use it for any profit-making activity or commercial gain

- You may freely distribute the URL identifying the publication in the public portal ?
}

Take down policy

If you believe that this document breaches copyright please contact us providing details, and we will remove access to the work immediately and investigate your claim. 
4 B.W. Zwartendijk, Department of Geography, University of Zürich, Switzerland, 5 bob.zwartendijk@live.nl.

6 H.J. van Meerveld, Department of Geography, University of Zürich, Switzerland, $7 \quad$ ilja.vanmeerveld@geo.uzh.ch.

8 C.P. Ghimire, Faculty of Geo-information and Earth Observation (ITC), University of

9 Twente, Enschede, The Netherlands, c_ghimire@yahoo.com.

10 L.A. Bruijnzeel, Department of Geography, King's College London, United Kingdom, 11 sampurno.bruijnzeel@kcl.ac.uk.

12 M. Ravelona, Laboratoire des Radio-Isotopes, University of Antananarivo, Antananarivo,

13 Madagascar, maafrav@gmail.com.

14 J.P.G. Jones, School of Environment, Natural Resources and Geography, Bangor

15 University, United Kingdom, julia.jones@bangor.ac.uk.

17 Corresponding author:

18 B.W.Zwartendijk (bob.zwartendijk@live.nl)

19 Department of Geography, Hydrology and Climate, University of Zürich, Switzerland.

20 Tel: +31642627196 
24 Land-use change due to the widespread practice of swidden agriculture affects the supply

25 of ecosystem services. However, there is comparatively little understanding of how the

26 hydrological functioning of soils, which affects rainfall infiltration and therefore flood

27 risk, dry-season flows and surface erosion, is affected by repeated vegetation clearing and

28 burning, the extent to which this can recover following land abandonment and vegetation

29 regrowth, and whether active restoration speeds up recovery. We used interviews with

30 local land users and indicator plant species to reconstruct the land-use history of 19

31 different sites in upland eastern Madagascar that represent four different land-use

32 categories: semi-mature forests that were never burnt but were influenced by manual

33 logging until 15-20 years ago; fallows that were actively reforested 6-9 years ago; 2-10

34 year old naturally regenerating fallows; and highly degraded fire-climax grassland sites.

35 Surface- and near-surface (down to $30 \mathrm{~cm}$ depth) saturated soil hydraulic conductivities

$36\left(K_{\text {sat }}\right)$, as well as the dominant flow pathways for infiltration and percolation were

37 determined for each land-cover type. Surface $K_{\text {sat }}$ in the forest sites was very high

38 (median: $724 \mathrm{~mm} \mathrm{~h}^{-1}$ ) and infiltration was dominated by flow along roots and other

39 preferential flow pathways (macropores), whereas $K_{\text {sat }}$ in the degraded land was low

40 (median: $45 \mathrm{~mm} \mathrm{~h}^{-1}$ ) with infiltration being dominated by near-surface matrix flow. The

41 total area of blue-dye stains was inversely correlated to the $K_{\text {sat. }}$ Both surface- and near-

42 surface $K_{\text {sat }}$ had increased significantly after 6-9 years of forest regeneration (median

43 values of 203 and $161 \mathrm{~mm} \mathrm{~h}^{-1}$ for reforestation and natural regeneration, respectively).

44 Additional observations are needed to more fully understand the rates at which soil

45 hydrological functioning can be rebuilt and whether active replanting decreases the time

46 required to restore soil hydrological functioning or not. 
47 Keywords: forest regeneration, reforestation, preferential flow pathways, saturated 48 hydraulic conductivity, runoff generation, swidden agriculture.

\section{Introduction}

51 Large areas of the agricultural-forest frontier in tropical countries are dominated by 52 swidden cultivation (also known as shifting cultivation or slash-and-burn agriculture; 53 Brady, 1996; Van Vliet et al., 2012). Swidden agriculture typically results in a mosaic of 54 land uses, including naturally regenerating fallows. Where population pressure is high and rotation cycles have shortened, it also results in extensive patches of highly degraded land that are no longer included in the agricultural rotation (Kleinman et al., 1995; Malmer et al., 2005, Bai et al., 2008). The ecological and soil fertility values of land in the various

58 phases of the swidden agricultural cycle, and the extent to which they improve during 59 forest regrowth, have received significant attention (Szott et al., 1999; Chazdon, 2014;

60 Mukul and Herbohn, 2016). However, despite the importance of water for rural 61 communities and ecosystems, our understanding of how the hydrological functioning of 62 tropical soils is impacted by repeated forest clearance and burning followed by vegetation 63 regrowth is still rather limited (e.g. Toky and Ramakrishnan, 1981; Gafur et al., 2003; 64 Ziegler et al., 2004). Also, evidence concerning the degree to which soil hydrological 65 functions may be restored by assisted regeneration (cf. Dugan, 2000) as opposed to full66 blown reforestation seems largely absent (Scott et al., 2005; Ilstedt et al., 2007).

67 The fire used in swidden agriculture can decrease soil organic carbon content, reduce 68 rooting density and depth, and decrease soil biotic activity (Fragoso et al., 1997; Lavelle et 69 al., 2001). Such changes can lead, in turn, to decreases in soil infiltration capacity and thus 70 increased surface runoff (Toky and Ramakrishnan, 1981; Ziegler et al., 2004). Excess 
71 surface runoff generation in the case of advanced soil degradation may even impair soil-

72 and groundwater recharge, which can have negative impacts on dry-season streamflow

73 and community water resources (Bruijnzeel, 2004; Forsyth and Walker, 2008).

74 In response to such problems, and to promote carbon sequestration, biodiversity, and rural

75 livelihoods, several major international initiatives (e.g. the Global Partnership on Forest

76 Landscape Restoration/IUCN, 2011; UN, 2015; cf. Aronson and Alexander, 2013; Lamb,

77 2014) have committed to restoring large areas of the world's degraded and deforested

78 land. However, the exact hydrological implications of such efforts, especially with respect

79 to changes in the streamflow regime, are under debate (Jackson et al., 2005; Scott et al.,

80 2005; Malmer et al., 2009). There are indications that the water use of vigorously

81 regenerating vegetation can exceed that of old-growth forest (Giambelluca et al., 2000; cf.

82 Ford et al., 2011) causing a reduction in streamflow during at least part of the succession

83 (Swank et al., 2001; Lacombe et al., 2015). On the other hand, total streamflow and

84 streamflow responses to rainfall are also influenced by soil hydrological functioning

85 (Bonell, 2005), which has been shown to improve during natural forest regeneration

86 (Ziegler et al., 2004; Zimmermann et al., 2010; Hassler et al., 2011) and after tree planting

87 on degraded soils (Bonell et al., 2010; Benegas et al., 2014). This improvement is thought

88 to reflect increases in soil organic matter, rooting density and depth, and, especially, soil

89 faunal activity and the development of preferential flow pathways (macropores) during

90 vegetation maturation (Colloff et al., 2010). As such, the quantification of rainfall

91 infiltration and related soil hydrological characteristics, and changes therein during forest

92 regeneration are important for understanding the hydrological effects of tropical land-use

93 change. 
94 A large proportion of Madagascar's renowned rain forest biome is now covered by a 95 mosaic of land uses representing different stages of the swidden agricultural cycle, 96 including highly degraded grasslands (Styger et al., 2007; Harper et al., 2007). Both 97 governmental and conservation organisations have attempted to slow or stop the practice 98 of swidden agriculture (Scales, 2014) and there have been occasional attempts at active 99 reforestation (Portela et al., 2012; Busch et al., 2012). Recently, the Malagasy Government 100 made a commitment to the United Nations Framework Convention of Climate Change to 101 reforest 270,000 ha with native species, and greatly reduce the national rate of 102 deforestation (Government of Madagascar, 2015). There have been claims that forest 103 restoration is important in terms of hydrological regulation (Portela et al., 2012) but 104 empirical studies of the effects of deforestation, forest regeneration or reforestation on soil 105 hydrological functioning in Madagascar are scarce and concern observations made more 106 than half a century ago (Bailly et al., 1974).

107 This study is part of a larger effort investigating the net hydrological impacts and 108 ecosystem services of various land-cover types associated with swidden agriculture and 109 forest regeneration in upland eastern Madagascar. The study region has experienced a long 110 history of swidden cultivation, as well as various conservation interventions aimed at 111 reducing forest clearance and burning, and, since 2005, active reforestation (Portela et al.,

112 2012). Interviews with local people, and plant indicator species were used to identify 11319 sites, which represented four widely occurring land-cover types (semi-mature forest, 114 actively reforested fallows, young naturally regenerating fallows, and degraded grass- and 115 shrub land). At these sites we investigated: (i) the differences in top-soil infiltration rates 116 and associated soil physical properties, and (ii) differences in preferential flow pathways 117 in order to determine how soil hydrological functioning is affected by land cover and 
118 whether active reforestation using native tree species results in a faster recovery of soil

119 hydrological functioning after land abandonment than natural forest regrowth.

\section{$120 \quad$ Materials and Methods}

\section{Research area}

122 The research was carried out in two communities (Andasibe and Ambatovola) in the

123 southern part of the Ankeniheny Zahamena Corridor (CAZ), which is a newly established

124 protected area and REDD+ pilot project area. The CAZ is widely recognised for its 125 extraordinary biodiversity (Le Saout et al., 2013). Swidden agriculture, in a system locally

126 known as tavy, has been practiced in the region for many generations and is considered a 127 major driver of deforestation (Styger et al., 2007; Clausen et al., 2013). The cutting and 128 burning of forest (primary or secondary) is typically followed by one or two seasons of 129 rice cultivation and a root crop the next season. The land is then left for natural fallow 130 regrowth, until the recovering vegetation is cleared again (Styger et al., 2007). Due to 131 rapid population growth, the length of the fallow cycle has decreased from 8-15 years in 132 the 1970's to as little as 3-5 years, resulting in degraded areas dominated by shrubs, ferns 133 and grasses (Styger et al., 2007). Some of the degraded fallows in the research area were 134 actively replanted with native tree species as part of the TAMS (Tetik Asa Mampody 135 Savoka) reforestation project, which started in 2005 and planted more than 120 native 136 species in more than 300 ha of degraded agricultural and forest land (Conservation 137 International, 2011). The reforested sites did not receive regular follow-up maintenance 138 (e.g. weeding of invasive species), and in most sites the trees are still relatively small 139 (<5 m height) and do not yet provide closed canopy conditions.

140 The study area is characterized by steep slopes $\left(>20^{\circ}\right)$ and broad valleys; elevations range

141 between 300 and $1800 \mathrm{~m}$ a.s.l. The area is underlain by Precambrian metamorphic and 
142 igneous basement rocks (granites, migmatites and schists) in which Oxisols and Ultisols

143 have developed (Hervieu and Randrianaridera, 1956; Du Puy and Moat, 1996). Based on

144 soil textural data down to $100 \mathrm{~cm}$ depth from the study area (Andriamananjara et al.,

145 2016), the soils in our study sites are classified as Tropudults and typically show an

146 increase in clay content at a depth of $60-70 \mathrm{~cm}$. The climate is tropical monsoonal

147 (Köeppen-type Am) with an average temperature at an elevation of $950 \mathrm{~m}$ a.s.1. (site

148 number 8 ) of $15^{\circ} \mathrm{C}$ during the dry season (April to October) and $22^{\circ} \mathrm{C}$ during the wet

149 season (November to March). Mean annual rainfall at Andasibe (990 m a.s.l.) was

$1501625 \mathrm{~mm} \mathrm{yr}^{-1}$ for the 1983-2013 period (Météo Madagascar, unpublished data, 2013).

151 Total rainfall measured with a tipping-bucket rain gauge (Rain Collector II, Davis

152 Instruments, Hayward, USA; $0.2 \mathrm{~mm}$ per tip) near Andasibe at site number 8 (Figure 1)

153 between October 2014 and September 2015 was $1650 \mathrm{~mm}$. The median, $95^{\text {th }}$ percentile

154 and maximum 5-min rainfall intensities during this period were $3.0,20$ and $150 \mathrm{~mm} \mathrm{~h}^{-1}$,

155 respectively, with corresponding values of $1.0,8.6$, and $95 \mathrm{~mm} \mathrm{~h}^{-1}$ for the 15 -min rainfall

156 intensities. Almost a third of the annual rainfall $(531 \mathrm{~mm})$ fell at a 5-min intensity $>20$

$157 \mathrm{~mm} \mathrm{~h}^{-1}$, while $41 \%(677 \mathrm{~mm})$ occurred at a 15 -min intensity $>8.6 \mathrm{~mm} \mathrm{~h}^{-1}$.

$<<$ Figure 1 $>>$

162 We wanted to sample sites that represented the four focal land-cover categories: $(i)$ semi163 mature forests that experienced heavy manual in the past but were never totally cleared 164 and burned. These forests contain mostly small trees with a few larger trees (diameter at breast height $\geq 20 \mathrm{~cm}$ ). It is likely that the latter represent remnant individuals that were 
considered too small to be harvested at the time of the latest harvesting (F); (ii) reforested

167 shrub/tree fallows (RF), where endemic trees were actively replanted between 2005 and

1682013 as part of the TAMS project; (iii) natural fallows (NF) dominated by shrubs and/or

169 trees of natural succession on abandoned agricultural land; and (iv) highly degraded

170 abandoned agricultural fields (DL) covered by scattered shrubs and grasses (fire-climax).

171 Undisturbed mature forests that have not been influenced by illegal logging, and older

172 fallows (>15 years) do not exist in the study area. We used a combination of previous

173 work that describes the plant species composition associated with different land-cover

174 stages (see Table 1), shape files showing reforested areas, and interviews with local

175 leaders and land users to identify the areas that represented our four focal land-cover

176 types. Within each land-cover category, we selected sites that were at least $120 \mathrm{~m}$ long and

$17775 \mathrm{~m}$ wide, without any major visual changes in vegetation or slope to minimise edge

178 effects. A total of 19 sites were selected (Figure 1 and Supplementary Material 1). At each

179 site measurements were taken at five locations at $15 \mathrm{~m}$ intervals along a $60 \mathrm{~m}$ transect.

180 The transects were located along the hillslope gradient to avoid bias by only including

181 upslope or downslope measurements (cf. Sobieraj et al., 2004; Ghimire et al., 2013).

$<\langle$ Table $1>>$

187 Soil cores $\left(100 \mathrm{~cm}^{3}\right)$ were taken at two depths $(12.5-17.5 \mathrm{~cm}$ and $22.5-27.5 \mathrm{~cm})$ at each

188 measurement point along a transect to determine porosity, moisture content at field 
capacity and bulk density. The moisture content at field capacity was defined as the

190 volumetric moisture content after three days of gravity drainage rather than following the

191 strict definition of the moisture content at a suction of $333 \mathrm{hPa}$ (Koorevaar et al., 1983).

192 The samples were saturated for 5 days, weighted, left to drain for 3 days and weighted 193 again at the Andasibe field station. The samples were oven dried $\left(24 \mathrm{~h}\right.$ at $\left.105{ }^{\circ} \mathrm{C}\right)$ at the

194 Laboratoire des Radio Isotopes (University of Antananarivo) and weighted again. Porosity

195 was determined following Klute (1986) by comparing the saturated weight and oven-dried

196 weight of the samples. Samples for soil textural analysis were taken at the same depths as

197 the cores and combined into one bulk sample per depth per transect. Particle size

198 distributions were analysed at the VU University in Amsterdam using a QUIXEL Helium-

199 Neon Laser Optical System (Sympatec GmbH, Clausthal-Zellerfeld, Germany). To ensure

200 that there were no significant changes in soil texture along a transect, soil texture was

201 determined at each measurement location in the field following Rowell (1994).

\section{$\underline{\text { Saturated hydraulic conductivity }}$}

203 The saturated soil hydraulic conductivity $\left(K_{\text {sat }}\right)$ describes the rate of steady-state

204 infiltration (at the surface) or percolation (at depth). $K_{\text {sat }}$ was measured at the soil surface, 205 at $10-20 \mathrm{~cm}$ and at $20-30 \mathrm{~cm}$ depths. These measurement depths correspond with the 206 main soil horizons in the study area and allow comparison of the results with other studies 207 (e.g. Godsey and Elsenbeer, 2002; Zimmermann et al., 2006, 2010). Steady-state surface 208 infiltration rates were determined using a portable double-ring infiltrometer $(15 \mathrm{~cm}$ inner 209 diameter, $21 \mathrm{~cm}$ outer diameter) that was inserted $9 \pm 3 \mathrm{~cm}$ into the soil, maintaining a 210 constant head of $10 \pm 3 \mathrm{~cm}$ ). These surface measurements were considered to represent the

$2110-10 \mathrm{~cm}$ layer. Values of sub-soil $K_{\text {sat }}$ were measured using a constant-head field 
212 permeameter (Amoozegar, 1989). The diameter of the auger hole was $6.0 \pm 0.5 \mathrm{~cm}$ at $10-$

$21320 \mathrm{~cm}$ depth and $5.6 \pm 0.5 \mathrm{~cm}$ at $20-30 \mathrm{~cm}$. The applied constant head was $17.5 \pm 1.5 \mathrm{~cm}$.

\section{Dye tracer experiments}

215 Dye tracer experiments were carried out to characterise the soils of the investigated land-

216 cover types in terms of their dominant infiltration and percolation patterns, i.e. matrix flow

217 (through soil pores) vs. preferential pathways (along roots and through macropores)

218 (Beven and Germann, 1982). Water with $2 \mathrm{~g} \mathrm{~L}^{-1}$ Brilliant Blue Dye (FCF C.I. 42090) was

219 sprayed on a $1 \mathrm{~m}^{2}$ plot at an average intensity of $20 \mathrm{~mm} \mathrm{~h}^{-1}$ in the middle of the transect at

220 six study sites (forest, $n=2$; reforestation, $n=1$; natural fallow, $n=1$; and degraded land,

$221 n=2$ ). Each plot was divided into two parts: the upper half received $20 \mathrm{~mm}$ of dye, the

222 lower half received $40 \mathrm{~mm}$. The irrigated plots were covered with a plastic sheet and the

223 soil was excavated the next day. Six sections were excavated per plot (three per

224 application rate), described qualitatively in the field and photographed for subsequent

225 analysis (cf. Weiler and Fluhler, 2004), to determine: (i) the so-called volume density (i.e.,

226 the fraction of soil that contained blue dye, representing the fraction of the soil where

227 water infiltrated), (ii) the fraction of blue stains narrower than $2 \mathrm{~cm}$ (indicating the 228 dominance of preferential flow pathways with little interaction with the matrix), and (iii)

229 the fraction of stains that were wider than $20 \mathrm{~cm}$ (indicating the dominance of preferential

230 flow pathways with high interaction with the matrix or homogeneous matrix flow).

\section{$231 \quad$ Data analysis}

232 Differences in bulk density, porosity, soil moisture content at field capacity, sand, silt, and 233 clay contents, as well as differences in $K_{\text {sat }}$ between the respective land-cover types were 234 tested for statistical significance by applying the Kruskal-Wallis analysis of ranks with 235 Dunn's method (Kruskal-Wallis, 1952). Differences were taken to be significant for 
values of $p<0.05$. Spearman rank correlation $\left(r_{\mathrm{s}}\right)$ analysis was used to determine the

237 correlation between $K_{\text {sat }}$ and the other soil physical characteristics.

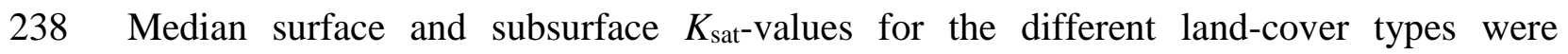
239 compared to the $95^{\text {th }}$ percentiles of the 5-min and 15-min rainfall intensities as measured 240 at Andasibe to infer the dominant runoff pathways (i.e. infiltration-excess overland flow 241 occurrence, vertical percolation, lateral subsurface flow or saturated overland flow; cf.

242 Bonell et al., 2010; Ghimire et al., 2014).

\section{Results}

\section{Soil physical characteristics}

245 Soil texture was either clay, clay loam, or sandy clay loam. Overall clay content at the 246 various study sites varied between 23 and 66\%, silt between 12 and 34\%, and sand 247 between 8 and 65\%. Although clay contents were highest (and sand contents lowest) for 248 the degraded land sites, the differences in sand, silt or clay contents between the land249 cover types were not significant (Table 2). Sand, silt and clay contents did not differ 250 significantly between the two depths intervals $(12.5-17.5 \mathrm{~cm}$ and $22.5-27.5 \mathrm{~cm})$ either.

251 Bulk density at $12.5-17.5 \mathrm{~cm}$ depth was significantly lower for the forest sites than for any 252 of the other land-cover types, but the differences at a depth of $22.5-27.5 \mathrm{~cm}$ between the 253 land cover types were small and not significant (Supplementary Materials 2 and 3a). 254 Likewise, differences in porosity (for either depth interval) between the different land cover types were small and not significant. Although the differences in moisture content at

256 field capacity between land cover types were larger than those for porosity, they were also 257 not significant (Supplementary Materials 2, 3b and 4a). Drainable porosity (i.e., total 258 porosity minus moisture content at field capacity) at $12.5-17.5 \mathrm{~cm}$ did not differ significantly between the different land cover types but at $22.5-27.5 \mathrm{~cm}$ the median value 
260 for the forest sites was significantly smaller than that for the degraded land sites

261 (Supplementary Materials 2 and 4b). The results for drainable porosity as a fraction of

262 total porosity were similar.

\section{Saturated hydraulic conductivity}

264 Values of saturated hydraulic conductivity $\left(K_{\text {sat }}\right)$ were generally higher for the forest sites

265 than for any other land cover (for all three measurement depths). However, the scatter in 266 the individual measurements was such that only the difference between the median $K_{\text {sat }}$ of

267 the relatively undisturbed forest soils $\left(724 \mathrm{~mm} \mathrm{~h}^{-1}\right)$ and that of the degraded land

$268\left(45 \mathrm{~mm} \mathrm{~h}^{-1}\right)$ was statistically significant (Figure $2 \mathrm{a}$ and Table 2). At a depth of 10-20 cm,

269 the median $K_{\text {sat }}$ for the forest sites $\left(87 \mathrm{~mm} \mathrm{~h}^{-1}\right)$ and reforestation sites $\left(56 \mathrm{~mm} \mathrm{~h}^{-1}\right)$ were

270 significantly higher than those for the natural fallows $\left(14 \mathrm{~mm} \mathrm{~h}^{-1}\right)$ and the heavily

271 degraded sites $\left(20 \mathrm{~mm} \mathrm{~h}^{-1}\right)$ (Figure $2 \mathrm{~b}$ and Table 2). At 20-30 $\mathrm{cm}$ depth, only the median

$272 K_{\text {sat }}$ of the forest $\left(4.3 \mathrm{~mm} \mathrm{~h}^{-1}\right)$ and that for the soil at the degraded land sites $\left(0.8 \mathrm{~mm} \mathrm{~h}^{-1}\right)$

273 differed significantly from each other (Figure 2c and Table 2).

$<<$ Table 2>>

$277 K_{\text {sat }}$ decreased quickly with depth at all sites (Figure 2 and Table 2). While the median 278 surface $K_{\text {sat }}$ exceeded the $95^{\text {th }}$ percentiles of the 5- and 15-min rainfall intensities for all 279 four land cover types (Figure $2 \mathrm{a}$ ), $K_{\text {sat }}$-values at $20-30 \mathrm{~cm}$ depth were well below these 280 intensities, regardless of land-cover type (Figure 2c). Median $K_{\text {sat }}$ at $10-20 \mathrm{~cm} \mathrm{depth}$ 281 beneath the forest sites and reforestation sites (87 and $56 \mathrm{~mm} \mathrm{~h}^{-1}$, respectively) was much 282 larger than the $95^{\text {th }}$ percentile of 5 -min rainfall intensity $\left(20 \mathrm{~mm} \mathrm{~h}^{-1}\right)$, while the median $K_{\text {sat }}$ 
283 for the young natural fallow sites $\left(14 \mathrm{~mm} \mathrm{~h}^{-1}\right)$ and degraded land $\left(20 \mathrm{~mm} \mathrm{~h}^{-1}\right)$ was similar 284 to the $95^{\text {th }}$ percentile of the 5-min rainfall intensity.

285 Median $K_{\text {sat }}$ per transect at 10-20 and at 20-30 cm was not significantly correlated with 286 the sand or clay contents. $K_{\text {sat }}$ at $10-20$ and at $20-30 \mathrm{~cm}$ was not significantly correlated 287 with the bulk density or porosity either (not known for $0-10 \mathrm{~cm}$ ). The $K_{\text {sat }}$ at $10-20 \mathrm{~cm}$ 288 depth was significantly correlated with moisture content at field capacity $\left(r_{\mathrm{s}}=0.23\right)$, 289 drainable porosity $\left(r_{\mathrm{s}}=-0.40\right)$, and the ratio of moisture content at field capacity and 290 porosity $\left(r_{\mathrm{s}}=0.40\right)$ at $12.5-17.5 \mathrm{~cm}$ depth. There was also a weak but statistically 291 significant correlation between $K_{\text {sat }}$ at $20-30 \mathrm{~cm}$ depth and the drainable porosity at 22.5$29227.5 \mathrm{~cm}\left(r_{\mathrm{s}}=-0.20\right)$. Taking the data for the reforestation and natural fallow sites together 293 (Figure 3), surface $K_{\text {sat }}$ appeared to increase with time since agricultural abandonment, 294 although the relationship was not particularly strong $\left(r_{\mathrm{s}}=0.42\right)$. The correlation improved $295\left(r_{\mathrm{s}}=0.68\right)$ when only considering the reforestation sites but was not significant for the 296 natural fallow sites. Values of $K_{\text {sat }}$ at $10-20 \mathrm{~cm}$ or $20-30 \mathrm{~cm}$ depth were not correlated 297 with time since abandonment.

$<<$ Figure 2>>

$<<$ Figure 3>>

304 There were no significant differences in the dye patterns or the maximum depth of dye 305 infiltration between the 20 and $40 \mathrm{~mm}$ applications. Therefore, results for the two 
applications were analysed together for each land-cover type. For the semi-mature forest,

307 as well as the reforestation/natural fallow sites, the infiltrated dye was located mainly

308 along larger macropores (Figure $4 \mathrm{a}$ and 4b). The forest soils were mostly characterized by

309 macropore flow with mixed interaction with the soil matrix (Figure 4a). The excavated

310 soil sections of the degraded land plots showed a more or less homogeneously stained top

311 layer $(0-15 \mathrm{~cm})$ where the fine roots were concentrated. The associated blue dye patterns

312 were mainly characterized by matrix flow and occasional 'fingering' (Figure 4). Where

313 macropore flow reached greater depth, it mainly occurred through worm holes or along

314 old roots and was characterised by relatively limited interaction with the soil matrix.

315 Infiltration patterns in the reforestation and young natural fallow sites varied considerably

316 between sections and could not be characterized by a single dominant flow type. Because

317 of this large variability and the small number of blue dye experiments, these sites were

318 further analysed as one land-cover category (RF/NF).

$<<$ Figure $4>>$

322 The difference in median maximum volume density between the forest sites and RF/NF

323 plots was significant, with the median value recorded for the forest $(0.72)$ being much

324 larger than the median for the younger regrowth $(0.23$; Table 3$)$. The fraction of stains

325 with a width larger than $20 \mathrm{~cm}$ was also greatest for the forest sites (median: 0.22) but the

326 difference with the other land cover types was not statistically significant (median of 0.00

327 for the RF/NF sites vs. 0.10 for the degraded land). The fraction of stains smaller than

$3282 \mathrm{~cm}$ was lower for the forest soil sections (median: 0.37 ) than for the RF/NF (median:

329 0.49) and degraded land sections (median: 0.63). Even though these differences were not 
statistically significant, they do suggest a trend towards more and larger macropores and

331 especially increased interaction with the soil matrix as vegetation regrows and the soil

332 recovers (Table 3). Further support for the increased importance of preferential flow

333 pathways in the sites with more mature vegetation comes from the fact that top-soil $K_{\text {sat }}$ $334(0-10 \mathrm{~cm})$ was inversely correlated $\left(r^{2}=0.72\right)$ with the total blue-stained area (median of 335 the 6 sections) per site; sites dominated by matrix flow had the largest blue dye stained 336 area in the upper soil layers (Figure 5 and Supplementary Material 5).

$338<<$ Table 3>>

$340<<$ Figure 5>>

\section{Discussion}

Limitations of the space-for-time substitution approach

344 Although the limitations of using space-for-time substitutions are well recognised (Pickett,

345 1989), very few studies of changes in saturated soil hydraulic conductivity $\left(K_{\text {sat }}\right)$ during

346 tropical vegetation regrowth on degraded soils have taken measurements in (near-) real

347 time after abandonment of agricultural land for cropping or grazing, or after tree planting

348 (e.g. Zimmermann et al., 2010; Patin et al., 2012; Ghimire et al., 2014). Like we did here,

349 the overwhelming majority of studies employed a space-for-time substitution (vegetation

350 chrono-sequences) approach for practical reasons (e.g. Gilmour et al., 1987; Deuchars et

351 al., 1999; Ziegler et al., 2004; Zimmermann et al., 2006; Hassler et al., 2011). An

352 important challenge in using chrono-sequences when investigating the impact of land- 
cover change over time is to eliminate the influence of inherent differences in soil

354 characteristics between sites and to reconstruct the land-use history at a particular location.

355 The first obstacle can be largely overcome by carefully selecting sites that have the same

356 soil type (Zimmermann et al. 2006). In this study, all plots were on the same metamorphic

357 rock type, had a similar soil type and sub-soil textural differences between land-cover

358 types were not statistically different. Further, $K_{\text {sat }}$ was not strongly correlated with soil

359 physical characteristics like bulk density or porosity, which suggests that differences in

360 soil type or texture did not affect $K_{\text {sat }}$ as much as land-cover type and that there was

361 sufficient initial pedological homogeneity to allow the respective sites to be compared.

362 Precise land-use history in the study area varies at a very fine scale across the landscape

363 and finding sites with a truly identical history to group together is difficult or impossible.

364 However, by using a combination of available secondary data (i.e. shape files from the

365 TAMS reforestation project; Conservation International, 2011), indicator plant species,

366 and key informant interviews we were able to identify sites falling into general categories

367 of past land use. Detailed interviews with local people at each site gave additional

368 information (such as time since abandonment), which allowed us to explore the impact of

369 land-use history on $K_{\text {sat. }}$

\section{Effect of land-cover type on saturated soil hydraulic conductivity}

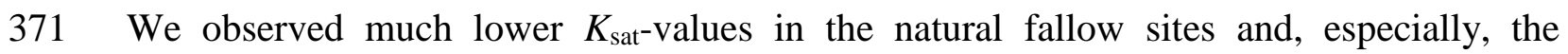

372 degraded land sites than in the forest sites (Table 2 and Figure 2). The differences in $K_{\text {sat }}$

373 between the degraded sites and the forest sites persisted to $30 \mathrm{~cm}$ depth. This suggests that

374 repeated burning and cropping cycles, combined with shortening recovery periods (Styger

375 et al., 2007), has a negative impact on soil hydrological properties down to a depth of at

376 least $30 \mathrm{~cm}$. This finding is similar to that of Ziegler et al. (2004), who found $K_{\text {sat }}$ at $40-$ 
$37770 \mathrm{~cm}$ depth beneath recently abandoned swidden fields and up to 20 year old

378 regenerating vegetation in northern Vietnam to be much lower than in the (disturbed)

379 forest (median values of $15-45,35-50$, and $80-85, \mathrm{~mm} \mathrm{~h}^{-1}$, respectively). Zimmermann et

380 al. (2006), working in SW Brazil, found that clearance for swidden agriculture followed

381 by a single season of cropping and 15 years of regrowth caused a hydrologically 382 insignificant decrease in soil infiltration capacity (from 1690 to $940 \mathrm{~mm} \mathrm{~h}^{-1}$, i.e. well 383 above maximum rainfall intensities), but they found a more pronounced effect when 384 clearance was followed by two years of cultivation and 20 years of grazed pasture (median $385 K_{\text {sat }}$ of $113 \mathrm{~mm} \mathrm{~h}^{-1}$ ). These effects were noticeable to at least $20 \mathrm{~cm}$ depth, although the 386 magnitude of change diminished rapidly with depth (Zimmermann et al., 2006).

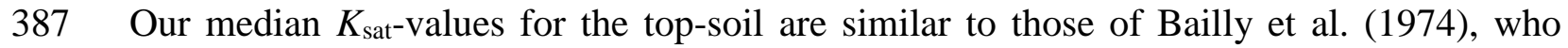
worked in our study area during the 1960s and early 1970s $\left(724 \mathrm{~mm} \mathrm{~h}^{-1} \mathrm{vs.} 720 \mathrm{~mm} \mathrm{~h}^{-1}\right.$ for

389 the forest sites and $161 \mathrm{~mm} \mathrm{~h}^{-1}$ vs. $115 \mathrm{~mm} \mathrm{~h}^{-1}$ for the young fallows/'old bush' sites).

390 However, literature values of median infiltrabilities for relatively young regenerating 391 forests $(<10$ years) replacing grazed pasture or swidden agriculture elsewhere in the 392 tropics are generally much lower (32-38 $\mathrm{mm} \mathrm{h}^{-1}$; Ziegler et al., 2004; Hassler et al., 2011) 393 than we recorded for the 6-9 year-old reforestation sites (203 $\mathrm{mm} \mathrm{h}^{-1}$, Table 2). 394 Corresponding published values for slightly older (12-20 years) successional vegetation 395 range from approximately $65 \mathrm{~mm} \mathrm{~h}^{-1}$ (Ziegler et al., 2004) through $160 \mathrm{~mm} \mathrm{~h}^{-1}$ (Hassler et 396 al., 2011) to 495-945 $\mathrm{mm} \mathrm{h}^{-1}$ (Deuchars et al., 1999; Zimmermann et al., 2006). Our 397 results for the semi-mature forest sites, which contain many trees that are 15-20 years old 398 fall also in the higher range of these values, although they cannot be direct compared 399 because they were never burned or cultivated. These differences in the median $K_{\text {sat-values }}$ 400 for our study sites and the literature values for other tropical areas likely reflect differences 401 in the intensity of the disturbance regime and initial $K_{\text {sat }}$ upon land abandonment (i.e. level 
402 of past soil degradation), as well as climatic (notably seasonality and length of dry season)

403 and inherent edaphic factors (soil fertility) that affect the rate of regrowth and

404 development of soil biological activity (Deuchars et al., 1999; Hairiah et al., 2006; Colloff

405 et al., 2010).

$406 \quad$ Recovery of soil hydrological functioning

407 We found that surface $K_{\text {sat }}$ increased with time since agricultural abandonment when the 408 results for the natural fallow and reforestation sites were combined but the trend was not 409 significant when considering the NF sites only. Median values of $K_{\text {sat }}$ at $20-30 \mathrm{~cm}$ depth 410 did not differ significantly for the natural fallow and reforestation sites either (Table 2).

411 Therefore, it is not clear from the measurements whether active reforestation decreases the

412 time needed for hydrological restoration of the soil compared to natural regeneration. This 413 could be due to the limited number of measurements ( $n=30$ for NF and $n=20$ for RF) or 414 that any difference is masked by differences in land-use history and the degree of 415 degradation prior to agricultural abandonment. In addition, the time since planting (6-9 416 years) or land abandonment (2-10 years) was likely too short to distinguish between the 417 two regenerative pathways. Unfortunately, older regenerating sites and reforested sites 418 cannot be found in the area. We, therefore, suggest that our measurements should be 419 repeated in the future (e.g. five and ten years and even further after the current 420 measurements) as the effects of active reforestation versus natural regeneration may take 421 longer to manifest than the age of sites available in this study.

422 We found no significant differences in $K_{\text {sat }}$ at $10-20 \mathrm{~cm}$ or $20-30 \mathrm{~cm}$ below the surface 423 between the natural fallow sites and the degraded grassland sites. Nor did we find a 424 significant increase in sub-soil $K_{\text {sat }}$ with time since land abandonment (Table 2). This 425 suggests that the subsurface $K_{\text {sat }}$ requires a (much) longer time to recover than surface $K_{\text {sat. }}$. 
426 Similar findings have been reported by Ziegler et al. (2004), Zimmermann et al. (2006),

427 and Hassler et al. (2011).

428 An increase in top-soil saturated hydraulic conductivity with time following the cessation

429 of agricultural activity has been reported in several other tropical studies (e.g., Deuchars et

430 al., 1999; Ziegler et al., 2004) but certainly not by all (e.g. de Moraes et al., 2006;

431 Zimmermann and Elsenbeer, 2008; Zimmermann et al., 2010). Patin et al. (2012) observed

432 a nearly eight-fold increase in surface $K_{\text {sat }}$ under fallow vegetation (no age given) during

433 annual repeated measurements over a period of six years (from 23 to $176 \mathrm{~mm} \mathrm{~h}^{-1}$ ) in Laos.

434 Similarly, large contrasts in the recovery of surface $K_{\text {sat }}$ have been reported after

435 abandonment of grazing land. Hassler et al. (2011) found an initial improvement in

436 median infiltrability after eight years of forest regeneration in Panamá (from 23 to 38

$437 \mathrm{~mm} \mathrm{~h}^{-1}$ ) followed by a rapid increase to $160 \mathrm{~mm} \mathrm{~h}^{-1}$ for $12-15$ year-old regrowth,

438 compared to $235 \mathrm{~mm} \mathrm{~h}^{-1}$ under old-growth forest. On the other hand, Zimmerman et al.

439 (2010) measured infiltrability and near-surface $K_{\text {sat }}$ for seven consecutive years during

440 natural succession on an abandoned pasture in SW Brazil and found a slight but non-

441 significant recovery during this period. A similar lack of change in surface $K_{\text {sat }}$ has been

442 reported by Zimmermann and Elsenbeer (2008) for 10-year-old regrowth in the

443 Ecuadorian Andes. They attributed this to arrested regeneration because succession was

444 dominated by bracken that prevented the establishment of pioneer tree species. While

445 Colloff et al. (2010) showed a steady increase in surface $K_{\text {sat }}$ and macropores with age of

446 plantations of eucalypts and Acacias, the difference with nearby pastures only became

447 significant after more than 11 years of growth.

448 Ilstedt et al. (2007) suggested in their review of the scant tropical literature that a three-

449 fold increase in surface $K_{\text {sat }}$ may be achieved, although they were hesitant to attach a time 
450 frame given the paucity of good-quality data. Ziegler et al. (2004) considered a natural

451 succession period of at least 25 years to be necessary to recover most of the surface $K_{\text {sat }}$ 452 after 2-4 years of swidden cultivation in upland Vietnam. Extrapolation of the initial 453 changes in infiltrability measured by Hassler et al. (2011) in Panamá suggests that full soil 454 physical recovery there might be achieved within ca. 20 years. Ghimire et al. (2014), 455 however, cautioned that reforestation per se does not guarantee an increase in $K_{\text {sat }}$ and the restoration of the hydrological system if a site is not properly managed (e.g. fire disturbance or repeated harvesting of litter and branches for animal bedding and

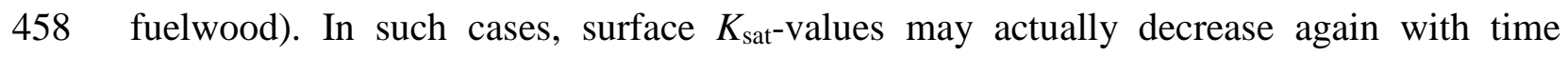

459 (Ghimire et al., 2014; Lacombe et al., 2015).

461 The infiltration capacity of clayey and silty soils is primarily affected by their organic matter content and the abundance and connectivity of preferential flow pathways

463 (Deuchars et al., 1999; Zhou et al., 2008). The blue dye patterns observed in this study 464 suggest that preferential flow caused the infiltration rates to be highest for the semi-mature 465 forest sites and lowest for the degraded land. Generally, the infiltration pattern was more uniform in the higher-conductivity top layer which is relatively rich in organic matter, while percolation in the lower-conductivity and more clayey layer at around $7.5-15 \mathrm{~cm}$ depth, occurred mainly along preferential flow pathways (Figure 4). The preferential flow 469 pathways were most abundant in the forest sites and less abundant in the reforestation, 470 natural fallows and degraded land sites. There were fewer preferential flow pathways in the degraded sites, but where they occurred, they allowed water to move deeper than in the 472 forest sites, in part because of the lower interaction with the matrix. While the dye 473 experiments were useful to visualize the differences in the infiltration and percolation 
474 pathways, the number of experiments was too small to determine any statistically

475 significant differences in the dye patterns between the land cover types. Additional 476 experiments are thus needed to see if there are differences in the maximum depth of the 477 dye or the volume density. These measurements could be combined with the device 478 advanced by Mendoza and Steenhuis (2002) that allows the separate measurement of 479 vertical and lateral fluxes.

480 A clear increase in preferential flow pathways (relative to those in adjacent pastures and 481 young tree plantations) was noted by Colloff et al. (2010) for 11-20-year-old tree 482 plantations, with most of the macropores attributed to the activity of soil invertebrates like 483 ants and termites. Hanson et al. (2004) showed for a site in Honduras that high surface 484 infiltration rates and well-connected preferential flow channels in an aggregated clayey 485 soil beneath primary forest resulted in rapid vertical infiltration to a depth of $35 \mathrm{~cm}$. However, in a nearby degraded grassland site that had been subject to repeated slash and 487 burn activity, infiltration rates were very low and excessive lateral flow occurred at and 488 just beneath the surface and very little water infiltrated below $10 \mathrm{~cm}$, even though 489 macropores were present below this depth. These findings were explained in terms of 490 blocking of near-surface macropores by fine sediment that was washed in from upslope 491 (Hanson et al., 2004). Benegas et al. (2014) reported that in a mixed land-use setting (tree 492 clumps within grazed pasture) in Costa Rica, preferential flow was only dominant close to 493 mature trees, while matrix flow increased with distance from the trees. This effect was 494 attributed to the combined action of tree root- and soil faunal activity beneath and in the 495 vicinity of trees (Benegas et al., 2014). Bachmair et al. (2009) studied dye infiltration 496 patterns in Germany in tilled and untilled farmland, pasture and deciduous forest and 497 found large differences in maximum infiltration depth for the different land uses. They 498 also found that larger rainfall applications resulted in deeper infiltration, except under 
499 forest. We did not find significant differences in the maximum depth of infiltration (or any

500 other parameter describing the blue dye patterns) for the 20 and $40 \mathrm{~mm}$ applications

501 (Table 3). Instead, the blue dye patterns and $K_{\text {sat }}$ profiles with depth suggest that most of

502 the infiltrated water stays in the top $30 \mathrm{~cm}$ of the soil or results in shallow lateral flow with

503 very little water percolating through the denser clay layers below.

$504 \quad$ Implications for runoff generation processes

505 Whether rainfall infiltrates into a soil or flows along the surface depends largely on the 506 magnitude of the surface $K_{\text {sat }}$ relative to the prevailing rainfall intensity, and, in addition, 507 on the change in $K_{\text {sat }}$ with depth (Elsenbeer, 2001; Bonell, 2005). The relatively high 508 surface $K_{\text {sat }}$-values exceed most rainfall intensities observed in the study area, suggesting 509 that infiltration-excess overland flow is a rather rare phenomenon. However, $K_{\text {sat }}$ 510 decreased sharply with depth for all land-cover types (Figure 2 and Table 2), as was also 511 reported for many other tropical studies (Godsey and Elsenbeer, 2002; Ziegler et al., 2004;

512 Zimmermann et al., 2006, 2010; Hassler et al., 2011). Rain water will thus percolate 513 vertically through the soil profile until meeting the first layer that has a lower $K_{\text {sat }}$ than the 514 incident precipitation rate, and will then start to accumulate above this layer (Figure 6).

515 Depending on the magnitude of the lateral $K_{\text {sat }}$ and the slope gradient, water will either 516 flow laterally above this impeding layer or saturate the soil layers above it. For large 517 rainfall events coinciding with high antecedent soil moisture conditions, this can lead to 518 saturation-excess overland flow (Elsenbeer, 2001; Bonell, 2005). Because of the relatively 519 low $K_{\text {sat }}$-values observed already at $10-20 \mathrm{~cm}$ depth in the young natural fallow sites and 520 the degraded sites (Table 2), less water will be needed there to fully saturate the soil and 521 generate saturation-excess overland flow at these sites than at the forest sites (Figure 6).

522 This difference can reflect the removal of the top layer in the more degraded sites by 
523 surface erosion during past cultivation periods (cf. Ziegler et al., 2004). In fact, surface

524 runoff was observed after 30 minutes of application of the blue dye at site number 15

525 (degraded land).

526

$527<<$ Figure 6>>

528

529 Enhanced surface runoff in the form of saturation- or infiltration-excess can lead to higher

530 peak flows, more soil erosion and subsequent declines in soil fertility and water quality

531 (Ziegler et al., 2009). It can also lead to decreased groundwater recharge and potentially

532 lower streamflow during the dry season (Bruijnzeel, 2004). Bailly et al. (1974) conducted

533 long-term catchment and erosion studies across Madagascar, including several sites

534 located near the current field sites. The catchment of Bailly et al. (1974) that was

535 classified as being under naturally regenerating vegetation ('brousse', no age given but

536 presumably less than 10 years old) was characterized by greater volumes of surface runoff

537 and higher peak flows compared to a nearby closed-canopy forest catchment. However,

538 Lacombe et al. (2015) reported gradually diminishing streamflow during 12 years of

539 natural regeneration in an area previously under swidden cultivation in Vietnam. Flows

540 declined both during the wet and the dry season due to a combination of better infiltration

541 and higher vegetation water use as the area under secondary forest expanded and matured

542 over time. Conversely, Beck et al. (2013) did not find any statistically significant trends in

543 long-term streamflow characteristics (high flows or low flows) when combining the

544 results for twelve meso-scale catchments in Puerto Rico undergoing major changes in

545 secondary forest cover. Different results were obtained for individual catchments,

546 suggesting significant spatial heterogeneity and highlighting the importance of including 
multiple sites when analysing land-cover impacts on hydrological functioning of tropical

548 catchments.

\section{$549 \quad$ Conclusions}

550 Swidden agriculture continues to be an important land-use practice in many tropical forest

551 areas. Understanding its influences on important soil- and water-related ecosystem

552 services is therefore important. Our study in eastern Madagascar shows that land 553 degradation, which can arise from swidden agriculture with short fallow cycles, changes

554 soil functioning in ways that reduce rainfall infiltration. Infiltration into the forest soil was

555 dominated by preferential flow with a high interaction with the soil matrix, while

556 infiltration in the degraded land was mainly due to matrix flow in the top soil layers. We

557 found a sharp decline in soil hydraulic conductivity with depth and a low hydraulic

558 conductivity relative to the prevailing rainfall intensities in the degraded sites, which

559 suggest that saturated overland flow in the degraded land is common. Enhanced overland

560 flow occurrence can result in progressive soil erosion and degradation and diminished

561 rates of soil water- and groundwater recharge, which may ultimately impact dry-season

562 flows in streams and rivers.

563 Our results, further, suggest that saturated soil hydraulic conductivity at the surface 564 increased after several years of land abandonment and forest regrowth. However, we

565 found no significant differences at $20-30 \mathrm{~cm}$ depth. Full hydrological recovery of

566 degraded sites with vegetation regrowth may, therefore, take several decades. Due to

567 differences in soil degradation before reforestation or natural regrowth, and the short time

568 span since reforestation $(<10$ years), it remains unclear whether active replanting 569 decreases the time required for soil hydrological restoration. Given the interest in active 570 forest restoration in Madagascar, as in many other areas of the tropics, further work is 
needed to more fully understand the rates at which soil hydrological functioning can be

572 rebuilt and to quantify the extent to which active replanting, rather than passive

573 regeneration, can contribute to more rapid rebuilding of soil- and water-related ecosystem

574 services.

\section{$575 \quad$ Acknowledgements}

576 This research is part of the p4ges project (Can Paying 4 Global Ecosystem Services values 577 reduce poverty?; www.p4ges.org) funded by the ESPA programme of the United 578 Kingdom (NE/K010220/1). We thank the people from the Andasibe, Ambatovola, 579 Ampangalatsary, and Maromizaha communities for their help with the fieldwork, access

580 to and background information on their land, and their invaluable contributions to this 581 study. We are grateful to our colleagues from the Laboratoire des Radio-Isotopes

582 (University of Antananarivo), particularly Herinsitohaina Razakamanarivo, Tantely 583 Razafimbelo and Andry Andriamananjara for help with field logistics and sharing 584 information on soil texture, which facilitated the classification of the soils of our study 585 sites, as well as Jocelyn Rakotondramanana, Andrea Sieber, and Tanjona

586 Rakotondramparany for help with the fieldwork; to our colleagues from the Association 587 Mitsinjo for logistical support; and to the people of Madagasikara Voakajy, Conservation 588 International Madagascar, and Alison Cameron (Bangor University) for useful discussion. 589 Thanks also to Jenny Hewson (Conservation International) for her input for Figure 1 and 590 to two anonymous reviewers for their constructive comments.

$\underline{\text { Research ethics }}$

592 The research was approved under the Bangor University Research Ethics framework. Soil

593 pits were backfilled to minimise damage. Field work was conducted under permits 594 provided by the Madagascar Ministry of Environment, Ecology, Sea and Forests 


\section{References}

600 Amoozegar, A. (1989). A compact constant-head permeameter for measuring saturated hydraulic 601 conductivity of the vadose zone. Soil Science Society of America Journal, 53(5), 1356-1361.

602

Andriamananjara, A., Hewson, J., Razakamanarivo, H., Andrisoa, R.H., Ntsoa, R., Ramboatiana, N., 604 Razafindrakoto, M., Ramifehiarivo, N., Razafimanantsoa, M.P., Rabeharisoa, L., Ramananantoandro, T., 605 Rasolohery, A., Rabetokotany, N., and Razafimbelo, T. (2016). Land cover impacts on aboveground and 606 soil carbon stocks in Malagasy rainforest. Agriculture, Ecosystems \& Environment Volume 233, 607 http://dx.doi.org/10.1016/j.agee.2016.08.030.

608 Aronson, J., and Alexander, S. (2013). Ecosystem restoration is now a global priority: Time to roll up our 609 sleeves. Restoration Ecology, 21: 293-296.

610 Bachmair, S., Weiler, M., and Nutzmann, G. (2009). Controls of land use and soil structure on water 611 movement: lessons for pollutant transfer through the unsaturated zone. Journal of Hydrology, 369, 241612252.

613 Bai, Z., Dent, D. L., Olsson, L., and Schaepman, M. (2008). Proxy global assessment of land degradation. 614 Soil Use and Management, 24(3), 223-234.

615 Bailly, C., de Coignac, G.B., Malvos, C., Ningre, J.M., and Sarrailh, J.M. (1974). Étude de l'influence du 616 couvert naturel et de ses modifications á Madagascar. Expérimentations en bassins versants élémentaires.

617 Cahiers Scientifiques, 4. Centre Scientifique Forestier Tropical, Nogent-sur-Marne, France, 114 pp.

618 Beck, H.E., Bruijnzeel, L.A., Van Dijk, A.I.J.M., McVicar, T.R., Scatena, F.N., and Schellekens, J. (2013). 619 The impact of forest regeneration on streamflow in 12 meso-scale humid tropical catchments. Hydrology 620 and Earth System Sciences, 17(7), 2613-2635. 
621 Benegas, L., Ilstedt, U., Roupsard, O., Jones, J., and Malmer, A. (2014). Effects of trees on infiltrability and 622 preferential flow in two contrasting agroecosystems in Central America. Agriculture, Ecosystems \& 623 Environment, 183, 185-196.

624 Beven, K. and Germann, P. (1982). Macropores and water flow in soils. Water Resources Research, 18(5), $625 \quad 1311-1325$.

626 Bonell, M. (2005). Runoff generation in tropical forests. In: Forests, Water and People in the Humid tropics,

627 Bonell, M., and Bruijnzeel, L.A., (Eds.). Cambridge University Press, Cambridge, U.K., pp 314-406.

628 Bonell, M., Purandara, B.K., Venkatesh, B., Krishnaswamy, J., Acharya, H.A.K., Singh, U.V., Jayakumar, 629 R., and Chappell, N. (2010). The impact of forest use and reforestation on soil hydraulic conductivity in 630 the Western Ghats of India: implications for surface and sub-surface hydrology. Journal of Hydrology, $631 \quad 391,47-62$.

632 Brady, N.C. (1996). Alternatives to slash-and-burn: a global imperative. Agriculture, Ecosystems \& 633 Environment, 58: 3-11.

634 Bruijnzeel, L. (2004). Hydrological functions of tropical forests: not seeing the soil for the trees? 635 Agriculture, Ecosystems \& Environment, 104, 185-228.

636 Busch, J., Dave, R., Hannah, L., Cameron, A., Rasolohery, A., Roehrdanz, P. and Schatz, G. (2012), Climate 637 change and the cost of conserving species in Madagascar. Conservation Biology, 26, 408-419. doi: $638 \quad 10.1111 / \mathrm{j} .1523-1739.2012 .01838 . x$.

639 Chazdon, R. (2014). Second Growth: The Promise of Tropical forest Regeneration in an Age of 640 Deforestation. University of Chicago Press, Chicago, USA.

641 Clausen, A., Brand, J., Faure, A., Giraud, P., Marre, J., Olivier, T., Andriamarozaka, I., Bekhechi, M., 642 Voninirina, A., and Razafintsalama, L. (2013). Madagascar Country Environmental Analysis (CEA), 643 Taking Stock and Moving Forward. Technical report, World Bank, Washington DC.

644 Colloff, M., Pullen, K., and Cunningham, S. (2010). Restoration of an ecosystem function to revegetation 645 communities: the role of invertebrate macropores in enhancing soil water infiltration. Restoration 646 Ecology, 18(S1), 65-72. 
647 Conservation International (2011). Ankeniheny-Zahamena Corridor, a field demonstration model. Satoyama

648 Initiative, http://satoyama-initiative.org/en/ankeniheny-zahamena-corridor-a-field-demonstration-model-

649 conservation-international-madagascar/, p. 10.

650 De Moraes, J.M., Schuler, A.E., Dunne, T., Figueiredo, R.D., and Victoria, R.L. (2006). Water storage and 651 runoff processes in plinthic soils under forest and pasture in Eastern Amazonia. Hydrological Processes, $652 \quad 20,2509-2526$

653 Deuchars, S., J.Townend, Aitkenhead, M., and FitzPatrick, E. (1999). Changes in soil structure and 654 hydraulic properties in regenerating rain forest. Soil Use and Management, 15, 183-187.

655 Dugan, P. (2000). Assisted natural regeneration: methods, results and issues relevant to sustained 656 participation by communities. In: Forest Restoration for Wildlife Conservation. Elliott, S., Kerby, J., 657 Blakesley, D., Hardwick, K., Woods, K., and Anusarnsunthorn, V. (Eds.). University of Chiang Mai, 658 Chiang Mai, Thailand.

659 Du Puy, D.J. and Moat, J. (1996). A refined classification of the primary vegetation of Madagascar based on 660 the underlying geology: using GIS to map its distribution and to assess its conservation status. In W.R. 661 Lourenço (editor), Proceedings of the International Symposium on the 'Biogéographie de Madagascar', 662 Paris, September 1995, pp. 205-218, + 3 maps. Editions de l’ORSTOM, Paris.

663 Elsenbeer, H. (2001). Hydrologic flowpaths in tropical rainforest soilscapes: a review. Hydrological 664 Processes, 15, 1751-1759.

665 Ford, C.R, Laseter, S.H., Swank, W.T., and Vose, J.M. (2011). Can forest management be used to sustain 666 water-based ecosystem services in the face of climate change? Ecological Applications, 21(6), 20496672067

668 Forsyth, T. and Walker, A. (2008). Forest Guardians, Forest Destroyers. The Politics of Environmental 669 Knowledge in Northern Thailand. University of Washington Press, Seattle, USA, 302 pp.

670 Fragoso, C., Brown, G.G., Patron, J.C., Blanchart, E., Lavelle, P., Pashanasi, B., Senapati, B., and Kumar, T. 671 (1997). Agricultural intensification, soil biodiversity and agroecosystem function in the tropics: the role of 672 earthworms. Applied Soil Ecology, 6, 17-35. 
673 Gafur, A., Jensen, J. R., Borggaard, O. K. and Petersen, L. (2003). Runoff and losses of soil and nutrients

674 from small watersheds under shifting cultivation (Jhum) in the Chittagong Hill Tracts of Bangladesh.

675 Journal of Hydrology, 274(1), 30-46.

676 Giambelluca, T.W., Nullet, M.A., Ziegler, A.D., and Tran, L. (2000). Latent and sensible heat energy flux 677 over deforested land surfaces in the Eastern Amazon and northern Thailand. Singapore Journal of 678 Tropical Geography, 21(2), 107-130.

679 Ghimire, C.P., Bonell, M., Bruijnzeel, L., Coles, N., and Lubczynski, M.W. (2013). Reforesting severely 680 degraded grassland in the Lesser Himalaya of Nepal: Effects on soil hydraulic conductivity and overland 681 flow production. Journal of Geophysical Research: Earth Surface, 118, 2528-2545.

682 Ghimire, C. P., Bruijnzeel, L. A., Bonell, M., Coles, N., Lubczynski, M. W. and Gilmour, D. A. (2014), The 683 effects of sustained forest use on hillslope soil hydraulic conductivity in the Middle Mountains of Central 684 Nepal. Ecohydrology, 7: 478-495. doi: 10.1002/eco.1367

685 Gilmour, D.A., Bonell, M., and Cassells, D.S. (1987). The effects of forestation on soil hydraulic properties 686 in the Middle Hills of Nepal: a preliminary assessment. Mountain Research and Development, 7(3), 239687249.

688 Global partnership on Forest Landscape Restoration/IUCN. (2011). The Bonn Challenge - Leaders define 689 pathways to restoring 150 million hectares of lost forests. www.iucn.org/?uNewsID=8147. Last visited $690 \quad 17 / 08 / 2016$.

691 Godsey, S. and Elsenbeer, H. (2002). The soil hydrologic response to forest regrowth: a case study from 692 southwestern Amazonia. Hydrological Processes, 16, 1519-1522.

693 Government of Madagascar. (2015). Madagascar's Intended Nationally Determined Contribution. 694 http://www4.unfccc.int/submissions/INDC/Published\%20Documents/Madagascar/1/Madagascar\%20IND 695 C\%20Eng.pdf . Last visited: 17/08/2016

696 Hairiah, K., Sulistyani, H., Suprayogo, D., Widianto Purnomosidhi, P., Harto Widodo, R., Van Noordwijk. 697 M. (2006). Litter layer residence time in forest and coffee agroforestry systems in Sumberjaya, West 698 Lampung. Forest Ecology and Management, 224, 45-57. 
699 Hanson, D., Steenhuis, T., Walter, M., and Boll, J. (2004). Effects of soil degradation and management 700 practices on the surface water dynamics in the Talgua river watershed in Honduras. Land Degradation and $701 \quad$ Development, 15, 367-381.

702 Harper, G., Steininger, M., Tucker, C., Juhn, D., and Hawkins, F. (2007). Fifty years of deforestation and 703 forest fragmentation in Madagascar. Environmental Conservation, 34(4), 325-333.

704 Hassler, S., Zimmermann, B., van Breugel, M., Hall, J., and Elsenbeer, H. (2011). Recovery of saturated 705 hydraulic conductivity under secondary succession on former pasture in the humid tropics. Forest 706 Ecology and Management, 261, 1634-1642.

707 Hervieu, J., and Randrianaridera, E. (1956). Carte pédologique de reconnaissance au 1/200.000, feuille no. 708 33, Moramanga- Brickaville. Technical report, ORSTOM, Paris.

709 Ilstedt, U., Malmer, A., Verbeeten, E., and Murdiyarso, D. (2007). The effect of afforestation on water 710 infiltration in the tropics: A systematic review and meta-analysis. Forest Ecology and Management, $711251(1-2), 45-51$.

712 Jackson, R. B., Jobbagy, E. G., Avissar, R., Roy, S. B., Barrett, D. J., Cook, C. W., Farley, K. A., Le Maître, 713 D. C., McCarl, B. A., and Murray, B. C. (2005). Trading water for carbon with biological carbon 714 sequestration, Science, 310, 1944-1947.

715 Klanderud, K., Mbolatiana, H.Z.H., Vololomboahangy, M.N., Radimbison, M.A., Roger, E., Totland, O., 716 and Rajeriarison, C. (2010). Recovery of plant species richness and composition after slash-and-burn 717 agriculture in a tropical rainforest in Madagascar. Biodiversity Conservation, 19, 187-204.

718 Kleinman, P.J.A., Pimentel, D. \& Bryant, R.B. (1995). The ecological sustainability of slash-and-burn 719 agriculture. Agriculture, Ecosystems \& Environment, 52 235-249.

720 Klute, A. (Ed.) (1986). Methods of Soil Analysis. Part 1. Physical and Mineralogical Methods. American 721 Society of Agronomy, Soil Science Society of America, Madison, Wisconsin, USA.

722 Koorevaar, P., Menelik, G., and Dirksen, C. (1983). Elements of Soil Physics, Developments in Soil 723 Science, 13. Elsevier Science Ltd., Amsterdam.

724 Kruskal, W. and Wallis, W. (1952). Use of ranks in one-criterion variance analysis. Journal of the American 725 Statistical Association, 47(260), 583-621. 
Lacombe, G., Ribolzi, O., de Rouw, A., Pierret, A., Latsachak, K., Silvera, N., Pham Dinh, R., Orange, D., Janeau, J.L., Soulileuth, B., Robain, H., Taccoen, A., Sengpaathith, P., Mouche, E., Sengtaheuanghoung, O., Tran Duc, T. and Valentin, C. (2015). Afforestation by natural regeneration or by tree planting: examples of opposite hydrological impacts evidenced by long-term field monitoring in the humid tropics. Hydrology and Earth System Sciences, Discussions, 12, 12615-12648.

Lamb, D. (2014). Large-Scale Forest Restoration. Earthscan. Routledge, London. ISBN-10: 0415663180. $301 \mathrm{pp}$.

Lavelle, P., Barros, E., Blanchart, E., Brown, G., Desjardins, T., Mariani, L., and Rossi, J. (2001). Soil organic matter management in the tropics: why feeding the soil macrofauna? Nutrient Cycling in Agroecosystems, 61, 53-61.

Le Saout, S., Hoffmann, M., Shi, Y., Hughes, A., Bernard, C., Brooks, T.M., Bertzky, B., Butchart, S.H.M., Conservation. Science, 342, 6160, pp. 803-805.

Malmer, A., van Noordwijk, M., and Bruijnzeel, L. A. (2005). Effects of shifting cultivation and forest fire. In: Forests, Water and People in the Humid Tropics. Bonell, M. and Bruijnzeel, L.A. (Eds.). Cambridge University Press, Cambridge, UK, 533-560.

Malmer, A., Murdiyarso, D., Bruijnzeel, L.A., and Ilstedt, U. (2009). Carbon sequestration in tropical forests and water: a critical look at the basis for commonly used generalizations. Global Change Biology, 16, $599-604$.

Météo Madagascar, unpublished data (2013). Precipitation data CAZ 1983-2013. Technical Report, Météo Madagascar, Ministère des Transports et de la Météorologie, Antananarive, Madagascar.

Mukul, S.A., and Herbohn, J. (2016). The impacts of shifting cultivation on secondary forests dynamics in the tropics: a synthesis of the key findings and spatio-temporal distribution of research. Environmental Science \& Policy, 55, 167-177.

Patin, J., Mouche, E., Ribolzi, O., Chaplot, V., Sengtahevanghoung, O., Latsachak, K.O., Soulileuth, B. and agricultural catchment in Lao PDR. Journal of Hydrology, 426-427, 79-92. 
Pickett, S.T.A. (1989). Space-for-time substitutions as an alternative to long-term studies. In: Likens, G.E.

Portela, R., Nunes, P., Onofri, L., Villa, F., Shepard, A., and Lange, G. (2012). Assessing and Valuing cosystem Services in Ankeniheny-Zahamena Corridor (CAZ), Madagascar: A Demonstration Case Study for the Wealth Accounting and the Valuation of Ecosystem Services (WAVES) Global Partnership, 56. visited: $17 / 08 / 2016$

Rowell, D. (1994). Soil Science: Methods and Applications. Taylor \& Francis Ltd, London, UK.

Scales, I.R. (2014). The future of conservation and development in Madagascar: time for a new paradigm? Madagascar Conservation \& Development, 9(1), 5-12.

Schatz, G.E., (2005). Generic Tree Flora of Madagascar. Royal Botanic Gardens, Kew \& Missouri Botanical Garden. Printed by Lightning Source, 477, ISBN: 1900347822.

Scott, D. F., Bruijnzeel, L. A., and Mackensen, J. (2005). The hydrological and soil impacts of forestation in Cambridge University Press, Cambridge, UK, 622-651 .

Sobieraj, J.A., Elsenbeer, H., and Cameron, G. (2004). Scale dependency in spatial patterns of saturated hydraulic conductivity. Catena 55(1), 49-77.

Styger, E., Rakontondramasy, H., Pfeffer, M., Fernandes, E., and Bates, D. (2007). Influence of slash-andburn farming practices on fallow succession and land degradation in the rainforest region of Madagascar. Agriculture, Ecosystems \& Environment, 119, 257-269.

Swank, W.T., Vose, J.M., and Elliott, K.J. (2001). Long-term hydrologic and water quality response Managemeent, 143, 163-178.

Szott, L. T., Palm, C. A., and Buresh, R. J. (1999). Ecosystem fertility and fallow function in the humid and subhumid tropics. Agroforestry Systems, 47, 163-196. doi:10.1023/A:1006215430432. 
781 Vogt, D., Messerli, P., Leisz, S., Castella, J.C., Jorgensen, L., Birch-Thomsen, T., Hett, C., Bech-Bruun,

782 T., Ickowitz, A., Vu, K.C., Yasuyuki, K., Fox, J., Padoch, C., Dressler, W., Ziegler, A.D. (2012). Trends, 783 drivers and impacts of changes in swidden cultivation in tropical forest-agriculture frontiers: A global 784 assessment. Global Environmental Change, 22(2), 418-429.

785 Weiler, M., and Fluhler, H. (2004). Inferring flow types from dye patterns in macroporous soils. Geoderma, $786 \quad 120,137-153$.

787 Zhou, X., Lin, H., and White, E. (2008). Surface soil hydraulic properties in four soil series under different 788 land uses and their temporal changes. Catena 73, 180-188.

789 Ziegler, A., Giambelluca, T., Tran, L., Vana, T., Nullet, M., Fox, J., Vien, T., Pinthong, J., Maxwell, J., and 790 Evett, S. (2004). Hydrological consequences of landscape fragmentation in mountainous northern 791 Vietnam: evidence of accelerated overland flow generation. Journal of Hydrology, 287, 124-146.

792 Ziegler, A.D. Bruun, T.B., Guardiola-Claramonte, M., Giambelluca, T.W., Lawrence, D., Thanh Lam, N. 793 (2009). Environmental consequences of the demise in swidden cultivation in montane mainland Southeast 794 Asia: hydrology and geomorphology. Human Ecology, 37, 361-373.

795 Zimmermann, B. and Elsenbeer, H. (2008). Spatial and temporal variability of soil saturated hydraulic 796 conductivity in gradients of disturbance. Journal of Hydrology, 361, 78-95.

797 Zimmermann, B., Elsenbeer, H., and de Moraes, J. (2006). The influence of land-use changes on soil 798 hydraulic properties: implications for runoff generation. Forest Ecology and Management, 222, 29-38.

799 Zimmermann, B., Papritz, A., and Elsenbeer, H. (2010). Asymmetric response to disturbance and recovery: 800 changes of soil permeability under forest-pasture-forest transitions. Geoderma, 159, 209-215. 
802 Table 1: Indicator species and fallow succession stages based on Styger et al. (2007),

803 Klanderud et al. (2010), and Schatz (2005).

\begin{tabular}{|c|c|c|c|}
\hline Species & Family & Fallow stage & $\begin{array}{l}\text { Cropping / } \\
\text { fallow cycle }\end{array}$ \\
\hline Solanum mauritianum Scop. & Solanaceae (tree) & Tree fallow & 1 \\
\hline Clidemia hirta (L.) D. Don & $\begin{array}{l}\text { Melastomataceae } \\
\text { (tree/shrub) }\end{array}$ & Shrub fallow (not dominant) & - \\
\hline Cryptocarya $\mathrm{R} . \mathrm{Br}$. & Lauraceae (tree) & - & - \\
\hline Croton L. sp. & Euphorbiaceae (tree) & Tree/shrub fallow & $1-2$ \\
\hline Tambourissa Sonn. & Monimiaceae (tree) & Tree/shrub fallow & $1-2$ \\
\hline Trema orientalis (Blume) & Ulmaceae (tree) & Tree fallow & $1-2$ \\
\hline $\begin{array}{l}\text { Harungana madagascariensis Lam. } \\
\text { Ex Poir }\end{array}$ & Clusiaceae (tree/shrub) & Tree/shrub fallow & $1-5$ \\
\hline Psiadia altissima & Asteraceae (shrub/tree) & Tree/shrub fallow & $1-6$ \\
\hline $\begin{array}{l}\text { Aframomum angustifolium (Sonn.) } \\
\text { K. Schum }\end{array}$ & $\begin{array}{l}\text { Zingiberaceae (shrub, } \\
\text { perennial herbaceous) }\end{array}$ & Shrub fallow (not dominant) & $2-6$ \\
\hline Lantana camara L. (invasive) & Verbenaceae (shrub) & Shrub fallow & $2-6$ \\
\hline Rubus moluccanus L. (invasive) & Rosaceae (shrub) & Shrub fallow & $2-6$ \\
\hline Imperata cylindrica (L.) Raeusch. & Poaceae (herb/grass) & Shrub fallow / grassland & $>3$ \\
\hline Pteridium aquilinum (L.) Kuhn & $\begin{array}{l}\text { Dennstaedtiaceae } \\
\text { (herbaceous, fern) }\end{array}$ & Shrub fallow & $3-7$ \\
\hline $\begin{array}{l}\text { Sticherus flagellaris (Bory ex Willd.) } \\
\text { Ching }\end{array}$ & Gleicheniacea (fern) & Shrub fallow & $3-7$ \\
\hline Aristida similis Steud & Poaceae (herb/grass) & Shrub fallow / grassland & $>6$ \\
\hline Hyparrhenia rufa (Nees) Stapf & Poaceae (herb/grass) & Shrub fallow / grassland & $>6$ \\
\hline Psorospermum Spach & Clusiaceae (shrub) & Shrub fallow / grassland & $>6$ \\
\hline
\end{tabular}


804 Table 2: Median soil hydraulic conductivity $\left(K_{\text {sat }}\right)$ and sand, silt and clay fractions, per

805 land-cover type. Different superscript letters denote statistically significant differences

806 between the land cover types.

\begin{tabular}{lllll}
\hline & $\mathrm{F}$ & $\mathrm{RF}$ & $\mathrm{NF}$ & $\mathrm{DL}$ \\
\hline $\mathrm{K}_{\text {sat }} 0-10{\mathrm{~cm}\left[\mathrm{~mm} \mathrm{~h}^{-1}\right]}$ & $724^{\mathrm{a}}$ & $203^{\mathrm{ab}}$ & $161^{\mathrm{ab}}$ & $45^{\mathrm{b}}$ \\
$\mathrm{K}_{\text {sat }} 10-20{\mathrm{~cm}\left[\mathrm{~mm} \mathrm{~h}^{-1}\right]}^{\mathrm{a}}$ & $87^{\mathrm{a}}$ & $56^{\mathrm{a}}$ & $14^{\mathrm{b}}$ & $20^{\mathrm{b}}$ \\
$\mathrm{K}_{\text {sat }} 20-30{\mathrm{~cm}\left[\mathrm{~mm} \mathrm{~h}^{-1}\right]}_{\text {Sand }[\%]^{*}}^{4.3^{\mathrm{a}}}$ & $0.9^{\mathrm{ab}}$ & $0.9^{\mathrm{ab}}$ & $0.8^{\mathrm{b}}$ \\
Silt [\% & 29.2 & 31.6 & 30.6 & 19.8 \\
Clay $[\%]^{*}$ & 27.2 & 26.7 & 21.3 & 26.0 \\
\hline
\end{tabular}

807 *No statistically significant differences found between land covers. Number of soil texture samples: F: 4; 808 RF: 6; NF: 11; DL: 8.

809

810 Table 3: Median values for the characteristics describing dye tracer patterns. Different

811 superscript letters denote statistically significant differences between land-cover types.

\begin{tabular}{llll}
\hline & F & RF/NF & DL \\
\hline Maximum depth of infiltrated blue dye [cm] & $31^{\mathrm{a}}$ & $25^{\mathrm{a}}$ & $35^{\mathrm{b}}$ \\
Maximum dye volume density [-] & $0.72^{\mathrm{a}}$ & $0.23^{\mathrm{b}}$ & $0.53^{\mathrm{ab}}$ \\
Fraction of stains smaller than $2 \mathrm{~cm} \mathrm{[-]}$ & $0.37^{\mathrm{a}}$ & $0.49^{\mathrm{a}}$ & $0.63^{\mathrm{a}}$ \\
Fraction of stains larger than $20 \mathrm{~cm} \mathrm{[-]}$ & $0.22^{\mathrm{a}}$ & $0.0^{\mathrm{a}}$ & $0.10^{\mathrm{a}}$ \\
Size of the stained area [cm²] & $364^{\mathrm{ab}}$ & $114^{\mathrm{a}}$ & $567^{\mathrm{b}}$ \\
\hline
\end{tabular}

812 